\title{
PIMAS
}

Jurnal Pengabdian Masyarakat

Homepage: http://ejournal.uhb.ac.id/index.php/PIMAS

\section{Desain Prototipe Portal Informasi Wisata Desa Candirenggo}

\author{
Retno Agus Setiawan ${ }^{1}$, , Imam Ahmad Ashari ${ }^{2}$, Alan Bayu Aji ${ }^{3}$ \\ ${ }^{1}$ Program Studi Sistem Informasi, Fakultas Sains dan Teknologi, Universitas Harapan Bangsa \\ ${ }^{2}$ Program Studi Teknologi Informasi, Fakultas Sains dan Teknologi, Universitas Harapan Bangsa \\ ${ }^{3}$ Program Studi Hukum, Fakultas Ilmu Sosial, Universitas Harapan Bangsa \\ 1'retnoagussetiawan@gmail.com*; ${ }^{2}$ imamahmadashari@uhb.ac.id; ${ }^{3}$ alanbayuaji@uhb.ac.id
}

Artikel History:

Received: 03-02-2022/ Received in revised form: 07-02-2022/ Accepted: 16-02-2022

\begin{abstract}
Candirenggo, a village located in Kebumen, has been listed as a developing tourism village. Candirenggo is rich in natural potential such as waterfall, caves, and various natural sceneries. However, due to the lack of publicity, Candirenggo is unknown to many peoples, which is defecting tourism development. The objective of this study is to develop and introduce the tourism website as a tool in promoting and marketing the tourism destination. This study was conducted with the stages of preparation, planning and development, training, and evaluation. As a result, this study has successfully prototyped a tourism website to fulfill user needs. The training was conducted to optimize the use of the prototyped system. In addition, the participants in this study enjoyed interacting with the prototyped system and found it easy to use.
\end{abstract}

Keywords : prototype design, tourism website, candirenggo tourism village

\begin{abstract}
ABSTRAK
Desa Candirenggo merupakan salah satu desa dari delapan belas desa yang berada di Kecamatan Ayah, termasuk ke dalam status desa berkembang dan ditetapkan sebagai desa wisata dengan memiliki banyak potensi alam seperti air terjun, goa alami, dan beberapa tempat lain dengan pemandangan alam yang bagus. Akan tetapi potensi alam yang dimiliki belum didukung dengan pengelolaan yang baik yang berdampak pada kurang diminatinya potensi wisata tersebut. Kurangnya media promosi turut mendukung minimnya jumlah kunjungan wisatawan ke desa Candirenggo. Kegiatan pengabdian ini bertujuan untuk mengembangkan dan mengenalkan portal informasi wisata desa Candirenggo sebagai media penyampaian dan penyebarluasan informasi potensi desa secara efektif. Dengan menggunakan pendekatan tahapan persiapan, perancangan dan pengembangan, pelatihan dan sosialisasi, dan evaluasi, tim pengabdi berhasil mengembangkan portal informasi wisata desa candirenggo sesuai dengan kebutuhan pengguna mitra. Kegiatan pelatihan administratif sistem dan pengelolaan konten juga berhasil dilaksanakan untuk mendukung optimalisasi fungsi sistem portal informasi wisata desa yang telah dikembangkan. Hasil evaluasi menunjukkan portal informasi wisata desa memiliki kinerja yang baik. Selain itu, hasil evaluasi juga menunjukkan bahwa pengguna mitra memiliki minat dan merasakan kemudahan dalam menggunakan sistem portal informasi wisata desa.
\end{abstract}

\section{Kata kunci : desain protoripe, portal informasi, wisata desa candirenggo}

\section{PENDAhULUAN (Kapital)}

Desa Candirenggo merupakan salah satu desa dari delapan belas desa yang berada di Kecamatan Ayah, Kabupaten Kebumen, Jawa Tengah. Desa Candirenggo memiliki luas wilayah 716 ha dengan jumlah penduduk 5.741 jiwa dan 2.002 KK (DISPERMADESDUKCAPIL Prov JATENG, 2020).

*Corresponding author. Tel.: +62 812-1567-0249

Email: retnoagussetiawan@uhb.ac.id 
Berdasarkan statistik Indeks Desa Membangun (IDM), desa Candirenggo termasuk ke dalam status desa berkembang (KDPDTT, 2021). Sejak tahun 2009 desa Candirenggo telah ditetapkan sebagai desa wisata dengan banyak potensi alamnya, namun sampai saat ini perkembangan wisata di desa Candirenggo tidak maksimal dengan jumlah kunjungan wisata yang cenderung menurun setiap tahunnya (Supriyanto, 2019).

Beberapa potensi wisata alam yang ada diantaranya Goa Petruk yang merupakan primadona dan ikon objek wisata di desa Candirenggo (Supriyanto, 2019). Goa Petruk memiliki banyak keunikan dan kelebihan dibandingkan tempat wisata lain, di antaranya adalah untuk wisata umum dan minat khusus. Selain Goa Petruk juga masih ada objek wisata alam lainnya yang selama ini dikelola oleh masyarakat. diantaranya adalah Tebing Putih terletak di Dusun Mandayana, Goa Liah, Goa Macan tereletak di Dusun Teba, Goa Duren Renteng tereletak di Dusun Karanggondong, Goa Simpenan, Goa Jemblongan, Goa Surupan, Goa Banyu, Goa Langse, Goa Kandangan, Goa Glatik, air terjun Curug dan Leses (Sugeng, 2020).

Potensi-potensi wisata alam di desa Candirenggo merupakan modal awal dalam mengembangkan desa wisata berbasis masyarakat. Namun dikarenakan pengelolaan yang kurang maksimal mengakibatkan kurang diminatinya potensi wisata alam tersebut. Kurangnya media promosi turut mendukung berkurangnya jumlah kunjungan wisatawan. Apabila dikelola dan dipromosikan dengan baik maka potensi wisata tersebut akan menjadi salah satu pemasukan pendapatan bagi desa. Dalam rangka pengenalan potensi yang dimiliki desa Candirenggo maka diperlukan salah satu media informasi yang baik salah satunya melalui pengelolaan website portal informasi wisata desa. Portal informasi wisata desa ini dapat digunakan sebagai media penyampaian dan penyebarluasan informasi potensi desa Candirenggo secara efektif.

Arthana, Tirtayani, Astawan, \& Adnyani (2020) dalam kegiatan pengabdiannya, menerapkan penggunaan website untuk optimalisasi pemasaran wisata desa Selat. Desa Selat merupakan salah satu desa yang berlokasi di Bali. Kegiatan pengabdian tersebut dilaksanakna diawali dengan tahapan persiapan, pengembangan website, dan evaluasi. Wesbite wisata desa dikembangkan untuk mengenalkan objek-objek wisata yang ada di desa Selat, Bali. Hasil pengabdian menunjukkan, website yang dikembangkan telah sesuai dengan kebutuhan pengelola webite desa Selat.

Selanjutnya Sutrisno \& Trisnawarman (2018) mengembangkan portal website desa sebagai bentuk kegiatan pengabdian di desa Pandowoharjo, kabupaten Sleman. Website desa dikembangkan dengan tujuan untuk memudahkan dalam penyebaran informasi dan membantu pengarsipan berita atau kegiatan instansi desa. Di akhir kegiatannya, tim pengabdi melakukan kegiatan pelatihan kepada perangkat desa tentang administrasi pengelolaan wesbite desa.

Berdasarkan beberapa kegiatan pengabdian di atas, diketahui portal website efektif digunakan untuk medukung optimalisasi kegiatan pemasaran. Maka dari itu, kegiatan pengabdian ini dilakukan dengan tujuan untuk mengembangkan portal informasi wisata desa sebagai media untuk mempromosikan wisata desa Candirenggo dengan beberapa tahapan meliputi persiapan, perancangan dan pengembangan, pelatihan dan sosialisasi, dan evaluasi.

\section{METODE PELAKSANAAN KEGIATAN (Kapital)}

Metode pelaksanaan kegiatan terdiri dari empat kegiatan utama yaitu Persiapan, Perancangan dan Pengembangan, Pelatihan dan Sosialisasi, dan Evaluasi seperti ditunjukkan pada Gambar 1.

Tahap persiapan: Pada tahap ini terdiri dari kegiatan utama yaitu melakukan identifikasi masalah. Identifikasi masalah dilakukan sebagai langkah awal untuk merumuskan apa saja yang dibutuhkan dan dijadikan bahan untuk perancangan sistem dan materi pelatihan dalam kegiatan pengabdian. Dalam tahap persiapan ini juga dilakukan pengumpulan data melalui observasi lapangan dan penelusuran pustaka.

Tahap perancangan dan pengembangan: Pada tahap ini, analisis kebutuhan sistem dilakukan untuk mendukung kinerja dan tujuan sistem. Selain itu, analisa dilakukan berdasarkan data yang diperoleh dari hasil observasi lapangan. Pada tahap ini juga dilakukan proses desain 
sistem dengan menggunakan pendekatan wireframe, bertujuan untuk menggambarkan konsep dan fungsi dari sistem yang akan dikembangkan. Pada akhir tahap ini menghasilkan sebuah prototipe sistem yang dikembangkan dengan mengikuti desain wireframe yang diusulkan.

Tahap pelatihan dan sosialisasi: Pada tahap ini, kegiatan pelatihan dan sosialisasi diberikan kepada mitra dengan tujuan untuk memperkenalkan sistem yang dikembangkan. Selain memperkenalkan sistem, kegiatan ini juga bertujuan untuk menggali kemampuan dan masukan dari mitra pengguna.

Tahap evaluasi: Pada tahap ini, kegiatan evaluasi dilakukan untuk melihat kinerja dari sistem yang dikembangkan. Selain itu minat pengguna juga diuji untuk melihat ketertarikan pengguna dalam menggunakan sistem yang dikembangkan.

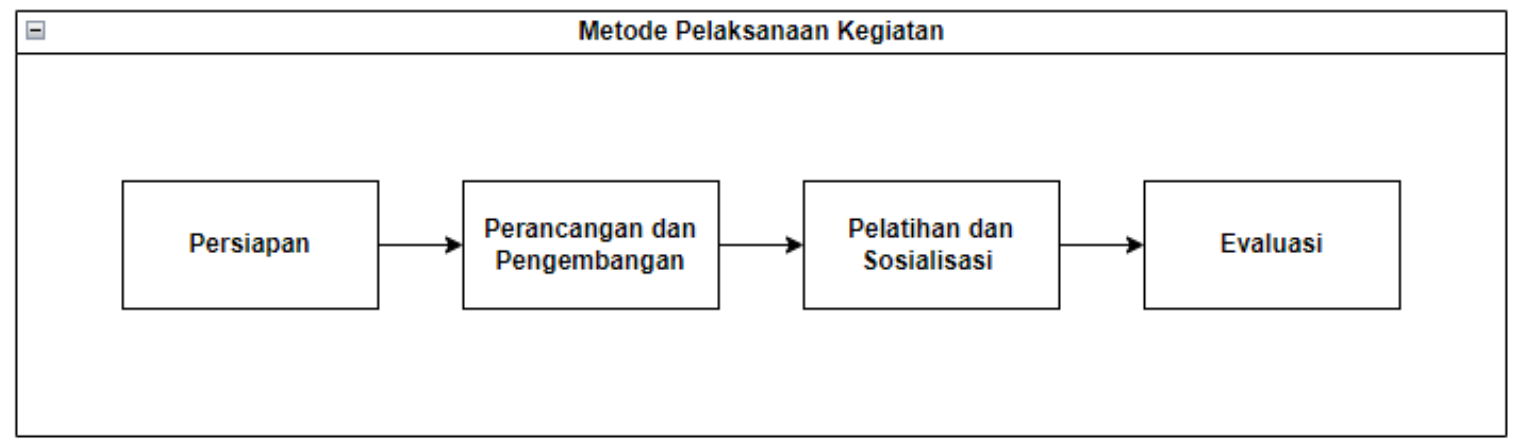

Gambar 1. Tahapan pelaksanaan kegiatan pengabdian

\section{HASIL KEGIATAN DAN PEMBAHASAN (Kapital)}

\subsection{Persiapan}

\section{Identifikasi Permasalahan Mitra}

Untuk menggali informasi terkait dengan permasalahan mitra, tim pengabdi melakukan observasi langsung ke lapangan. Kegiatan dimulai dengan penyusunan rencana kerja dan melakukan survey lapangan untuk mengidentifikasi permalasalahan yang ada di desa Candirenggo terkait program potensi wisata desa sehingga dapat dicarikan solusinya.

Kegiatan survey ini menghasilkan kesepakatan hasil diskusi dengan kepala desa Candirenggo Bapak Mustofa dan perangkat desa lainnya, yaitu pembuatan sebuah portal informasi wisata desa untuk memperluas jangkauan promosi dalam memperkenalkan potensi-potensi wisata kepada calon pengunjung atau masyarakat umum secara luas. Dalam proses diskusi juga disepakati terkait dengan kebutuhan data yang akan ditampilkan pada situs web wisata desa seperti profil desa, peta wisata dan destinasi wisata, kuliner desa, dan akomodasi.

Dalam kegiatan survey lapangan, tim pengabdi ditemani salah satu anggota BUMDes yang juga sebagai pengurus wisata desa, mengunjungi beberapa destinasi wisata. Salah satunya adalah curug gemawang yang sedang dipersiapkan sebagai salah satu destinasi utama wisata desa Candirenggo. Tim pengabdi berkesempatan mengambil beberapa gambar yang menunjukkan keadaan curug gemawang. Terlihat akses jalan cukup memadai dengan kondisi jalan sudah terpasang paving blok seperti ditunjukkan Gambar 2. 


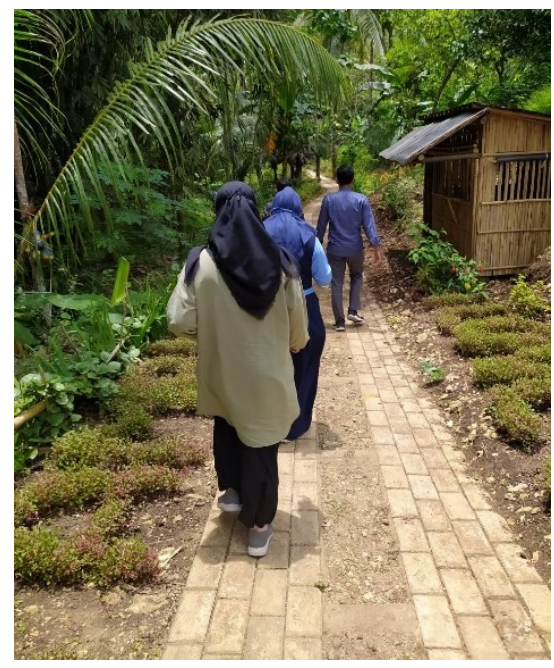

Gambar 2. Akses jalan menuju destinasi wisata curug gemawang

Selanjutnya potensi curug gemawang terlihat dari debit air terjun yang cukup deras seperti ditunjukkan pada Gambar 3. Hasil pengamatan gambar yang berhasil dikumpukan nantinya akan digunakan sebagai bahan atau materi yang akan ditampilkan pada situs web wisata desa.

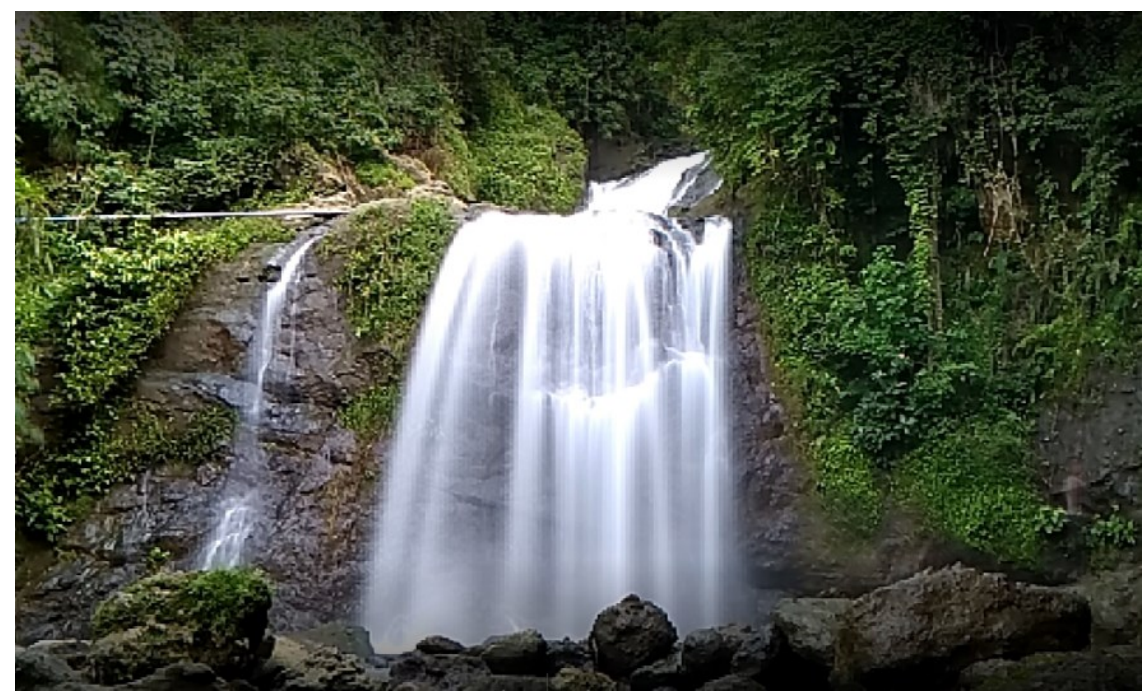

Gambar 3. Air terjun curug gemawang

\subsection{Perancangan dan Pengembangan}

Setelah proses identifikasi masalah mitra dan pengumpulan data selesai dilaksanakan, langkah selanjutnya adalah melakukan perancangan dan pengembangan sistem wisata desa. Pada tahap ini identifikasi kebutuhan sistem dilakukan dengan berdiskusi bersama dengan tim perangkat desa Candirenggo untuk menentukan fungsi utama dari sistem yang dikembangkan. Setelah muncul kesepakatan, tim pengabdi memulai proses perancangan dengan menyajikan desain sketsa Wireframe sebagai konsep desain awal pengembangan sistem wisata desa Candirenggo. Sketsa Wireframe berbentuk kerangka dasar dalam bentuk grafik dapat dilihat pada Gambar 4 . 


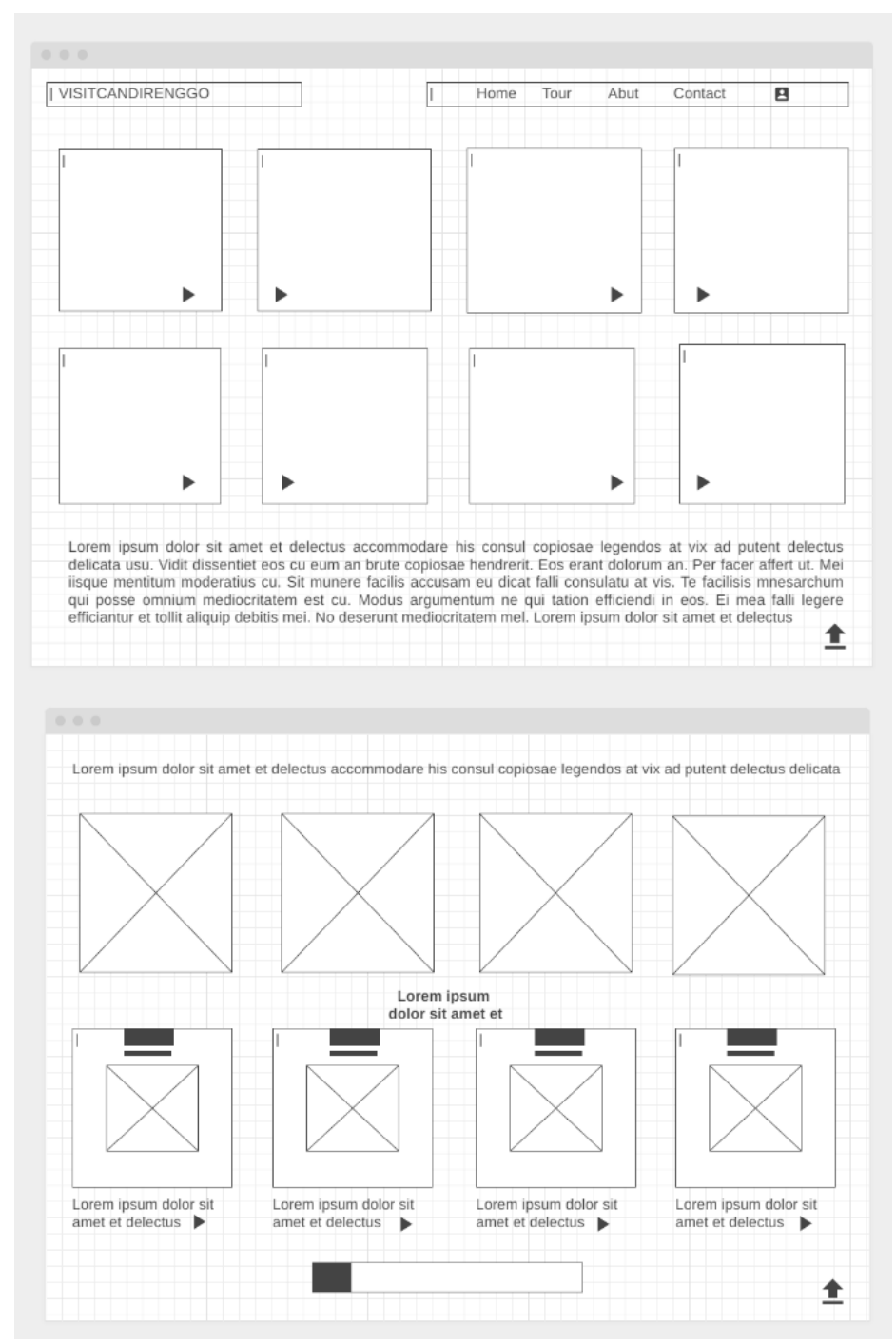

Gambar 4. Desain wireframe portal informasi wisata desa

Selanjutnya, proses pengembangan dimulai dengan menerjemahkan sketsa wireframe ke dalam bentuk prototipe sistem yang dinamis dan interaktif. Penyertaan dan penyesuaian konten dilaksanakan dengan tujuan untuk menghasilkan sebuah tampilan situs web yang mengedepankan pengalaman pengguna. Penempatan elemen gambar dan text pada bagian atas halaman situs web bertujuan untuk mempertegas fungsi utama dari sistem portal wisata desa. Pengaturan elemen-elemen tersebut bertujuan untuk memberikan efek dan efisiensi secara maksimum kepada pengunjung (Garrett, 2011), sehingga pengunjung bisa dengan mudah memahami fungsi utama dari portal informasi wisata desa. Selanjutnya untuk meningkatkan pengalaman pengguna dan membangun kepercayaan pengunjung terhadap situs web wisata desa Candirenggo, maka elemen seperi tipografi, warna, gambar, dan elemen visual lainnya diselaraskan. Penyelarasan elemen-elemen tersebut berfungsi untuk mendukung penyampaian konten atau fungsi froduk dari situs web wisata desa, seperti yang diusulkan oleh (Knight, 2019).

Adapun prototipe portal informasi wisata desa Candirenggo dapat dilihat pada Gambar 5 dan bisa diakses melalui laman https://fileags.wixsite.com/visitcandirenggo. 
VISITCANDIRENGGO
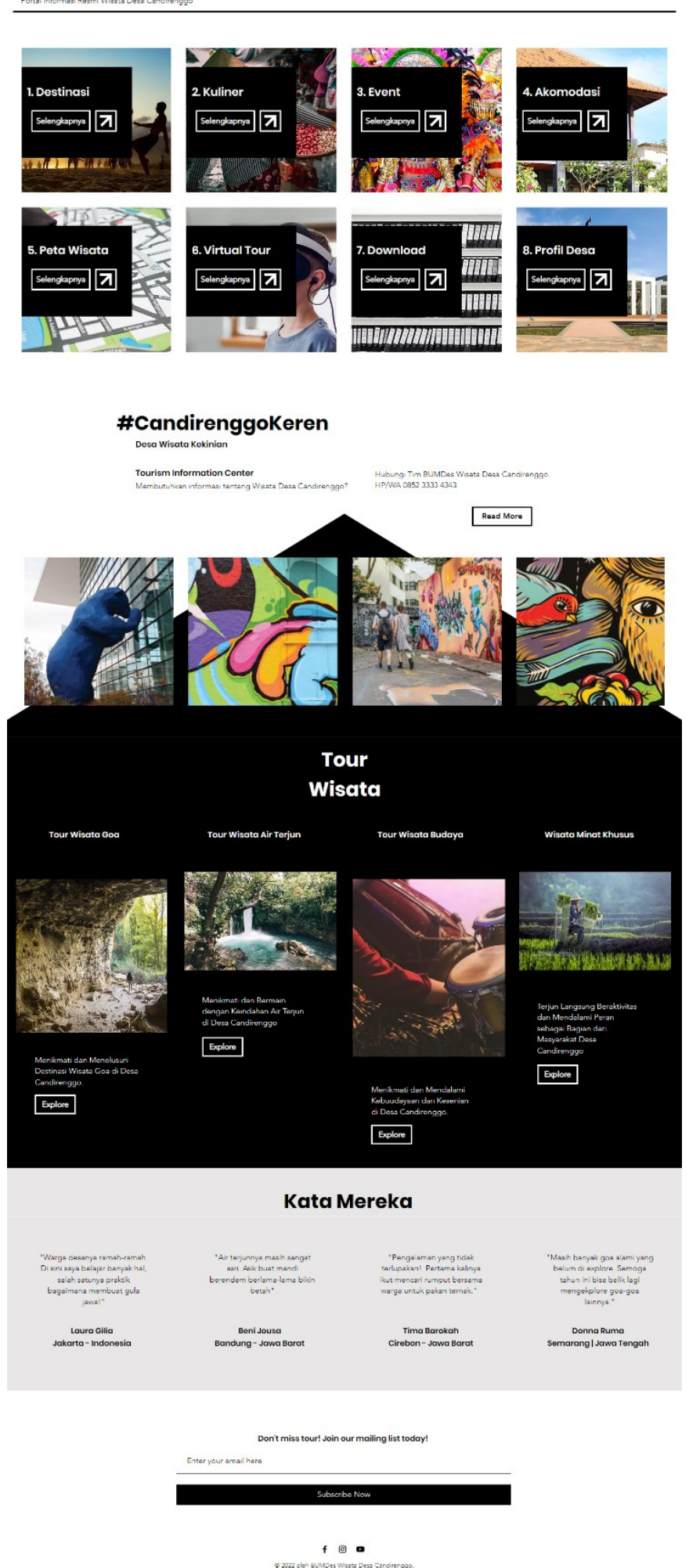

Gambar 5. Prototipe portal informasi wisata desa Candirenggo 


\subsection{Pelatihan dan Sosialisasi}

Setelah sistem portal informasi wisata desa berhasil dikembangkan, langkah selanjutnya adalah melakukan pelatihan dan sosialiasi kepada mitra. Kegiatan pelatihan dilaksanakan di aula balaidesa Candirenggo, dengan tujuan untuk memperkenalkan fungsi utama dari sistem portal informasi wisata desa. Selain memberikan pelatihan administratif pengelolaan, tim pengabdi juga memberikan pelatihan terkait dengan best practice penulisan konten pada portal informasi wisata desa. Suasana pelatihan dan sosialisasi ditunjukkan pada Gambar 6.

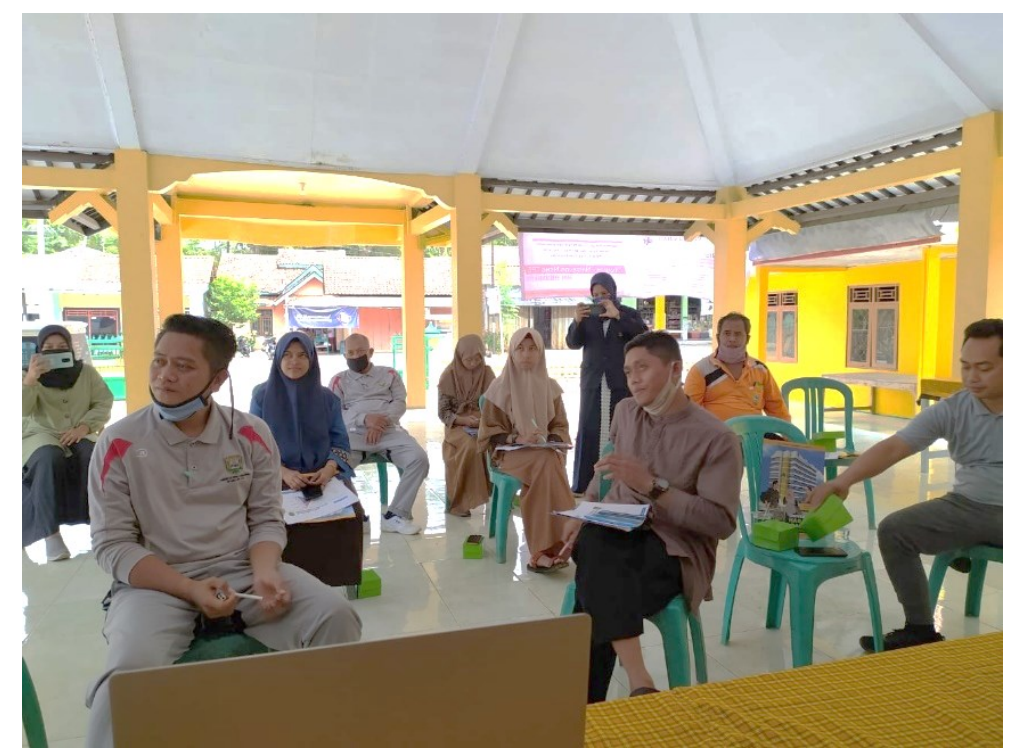

Gambar 6. Pelatihan dan sosialisasi kepada mitra

\subsection{Evaluasi}

Untuk menguji kinerja sistem, beberapa peserta pelatihan dan sosialisasi dari mitra diminta untuk menjalankan beberapa test-scenario seperti mencari informasi terkait destinasi wisata, profil desa, dan paket tour wisata. Hasilnya seperti ditunjukkan pada Tabel 1, semua skenario pengujian berhasil dijalankan.

Tabel 1. Pengujian fungsi pencarian

\begin{tabular}{|c|c|c|c|c|c|c|}
\hline Test Sce & Menca & rmasi wisata desa & irenggo & & & \\
\hline Pre-Condi & on: $\begin{array}{l}\text { - Penggu } \\
\text { - Penggu }\end{array}$ & $\begin{array}{l}\text { memiliki akses memb } \\
\text { a mengetahui portal in }\end{array}$ & $\begin{array}{l}\text { ka brows } \\
\text { rmasi wi }\end{array}$ & desa Candirenggo & & \\
\hline $\begin{array}{l}\text { Test Case } \\
\text { ID }\end{array}$ & $\begin{array}{l}\text { Test } \\
\text { Scenario }\end{array}$ & Test Steps & $\begin{array}{l}\text { Test } \\
\text { Data }\end{array}$ & $\begin{array}{l}\text { Expected } \\
\text { Results }\end{array}$ & Actual Results & $\begin{array}{l}\text { Pass } \\
\text { /Fail }\end{array}$ \\
\hline R1 & $\begin{array}{l}\text { Cek } \\
\text { informasi } \\
\text { destinasi } \\
\text { witasa desa } \\
\text { Candirenggo }\end{array}$ & 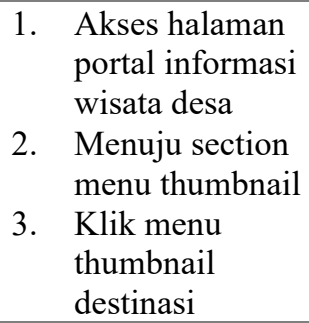 & - & $\begin{array}{l}\text { Menuju } \\
\text { halaman } \\
\text { destinasi wisata } \\
\text { desa } \\
\text { Candirenggo }\end{array}$ & $\begin{array}{l}\text { Menuju } \\
\text { halaman } \\
\text { destinasi wisata } \\
\text { desa } \\
\text { Candirenggo }\end{array}$ & Pass \\
\hline R2 & $\begin{array}{l}\text { Cek fungsi } \\
\text { pencarian }\end{array}$ & 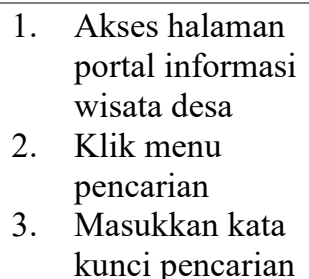 & $\begin{array}{l}\text { Kata } \\
\text { kunci: } \\
\text { Paket } \\
\text { tour } \\
\text { wisata }\end{array}$ & $\begin{array}{l}\text { Muncul hasil } \\
\text { pencarian yaitu } \\
\text { informasi paket } \\
\text { tour wisata desa } \\
\text { Candirenggo }\end{array}$ & $\begin{array}{l}\text { Muncul hasil } \\
\text { pencarian yaitu } \\
\text { informasi paket } \\
\text { tour wisata desa } \\
\text { Candirenggo }\end{array}$ & Pass \\
\hline
\end{tabular}


Selanjutnya untuk menguji minat pengguna, kuesioner paper dibagikan kepada mitra. Beberapa daftar pertanyaan dan jawaban dapat dilihat pada Tabel 2 dan Tabel 3.

Tabel 2. Daftar pernyataan paper kuesioner

\begin{tabular}{cl}
\hline No & \multicolumn{1}{c}{ Pernyataan } \\
\hline $\mathbf{1}$ & Kemudahan akses portal informasi wisata desa \\
\hline $\mathbf{2}$ & Kelengkapan menu informasi wisata desa \\
\hline $\mathbf{3}$ & $\begin{array}{l}\text { Portal informasi wisata desa membantu dalam } \\
\text { optimalisasi promosi wisata desa Candirenggo }\end{array}$ \\
\hline $\mathbf{4}$ & $\begin{array}{l}\text { Saya akan menggunakan portal informasi desa untuk } \\
\text { mencari informasi terkait potensi wisata desa } \\
\text { Candirenggo }\end{array}$ \\
\hline
\end{tabular}

Tabel 3. Jawaban responden mitra

\begin{tabular}{cccccc}
\hline Pernyataan & STS & TS & T & ST & SST \\
\hline $\mathbf{1}$ & 0 & 0 & 1 & 10 & 4 \\
\hline $\mathbf{2}$ & 0 & 0 & 3 & 9 & 3 \\
\hline $\mathbf{3}$ & 0 & 0 & 0 & 9 & 6 \\
\hline $\mathbf{4}$ & 0 & 0 & 0 & 10 & 5 \\
\hline $\begin{array}{l}\text { STS (Sangat tidak setuju); TS (Tidak Setuju); T (Tidak tahu); } \\
\text { ST (Setuju); SST (Sangat setuju) }\end{array}$ & & &
\end{tabular}

Hasil dari pengujian yang dilakukan berupa prosentase minat pengguna terhadap sistem portal informasi wisata desa. Dari proses pembobotan pada Tabel 4, dilakukan perhitungan prosentase maksimal. Hasil prosentase maksimal menunjukkan sebagian besar responden mitra $(73,34 \%)$ berniat untuk menggunakan sistem portam informasi wisata desa yang telah dikembangkan.

$$
\% \text { Maksimal }=\frac{254}{375} \times 100 \%=73,34 \%
$$

Tabel 4. Jawaban responden mitra

\begin{tabular}{cccc}
\hline Grade & Skor & Pernyataan & Hasil \\
\hline STS & 1 & 0 & 0 \\
\hline TS & 2 & 0 & 0 \\
\hline T & 3 & 4 & 12 \\
\hline ST & 4 & 38 & 152 \\
\hline SST & 5 & 18 & 90 \\
\hline
\end{tabular}

\section{SIMPULAN}

Kegiatan pengabdian kepada masyarakat ini dilakukan untuk mengenalkan teknologi informasi khususnya portal informasi website sebagai media untuk memperluas jangkauan promosi dalam memperkenalkan potensi wisata desa Candirenggo kepada konsumen atau masyarakat umum secara luas. Hasil dari kegiatan pengabdian ini, tim pengabdi berhasil mengembangkan sebuah portal informasi wisata desa yang dapat dikelola secara baik dan dapat diakses secara online dengan memanfaatkan fasilitas internet yang memadai. Bentuk kegiatan pelatihan diberikan untuk mengenalkan fungsi-fungsi yang terdapat pada sistem portal informasi wisata desa. Selain itu pelatihan best-practice penulisan konten juga diberikan kepada mitra untuk menunjang optimalisasi kegiatan promosi wisata desa secara luas. Di akhir kegiatan, hasil evaluasi menunjukkan kinerja sistem portal informasi wisata desa dapat berkerja dengan baik. Selain itu hasil evaluasi juga menunjukkan minat pengguna mitra untuk menggunakan sistem portal informasi wisata desa cukup tinggi. 


\section{SARAN}

Untuk mengoptimalkan fungsi dari sistem portal informasi yang dikembangkan, mitra perlu mensosialisasikan keberadaan sistem ini kepada masyarakat luas. Selain itu mitra perlu untuk membentuk tim khusus yang bertugas mengelola sistem portal informasi wisata desa mulai dari fungsi administratif sampai dengan fungsi konten.

\section{DAFTAR PUSTAKA}

Arthana, K. R., Tirtayani, L. A., Astawan, I. G., \& Adnyani, K. E. K. (2020). Penerapan Website untuk Optimalisasi Pemasaran Online Wisata Desa Selat. Proceeding Senadimas Undiksha, 1864-1870.

DISPERMADESDUKCAPIL Prov JATENG. (2020). Kependudukan Desa Candirenggo. Retrieved April 23, 2021, from https://sidesa.jatengprov.go.id/desa/33.05.01.2013

Garrett, J. J. (2011). The Elements of User Experience: User-Centered Design for The Web and Beyond (2nd Editio). Barkeley,CA: New Riders.

KDPDTT. (2021). Indeks Desa Membangun. Retrieved from https://idm.kemendesa.go.id/status

Knight, W. (2019). UX for Developers. https://doi.org/10.1007/978-1-4842-4227-8

Sugeng. (2020). Potensi Desa Candirenggo. Retrieved from https://candirenggo.kecayah.kebumenkab.go.id/index.php

Supriyanto. (2019). Model Pendidikan Kepariwisataan Dalam Pengembangan Desa Wisata Berbasis Masyarakat di Desa Candirenggo Kecamatan Ayah Kabupaten Kebumen. Jurnal Sosial Soedirman, 3(2), 49-63. https://doi.org/10.20884/juss.v3i2.2333

Sutrisno, T., \& Trisnawarman, D. (2018). Pembuatan dan Implementasi Website Desa Pandowoharjo. Jurnal Bakti Masyarakat Indonesia, 1(2), 211-220. 